\title{
Prognostic Value of High Sensitive Troponin T in Patients with Chronic Ischemic Heart Disease Undergoing Percutaneous Coronary Intervention
}

\section{Halil Aktaşa, Onur Kaypaklib, Caglar Ozmenc, Murat Gula, Oguz Yıldırımd, Sinan Incia , Ali Denizc, Mustafa Demirtasc}

a Faculty of Medicine, Aksaray University, Aksaray, Turkey

${ }^{b}$ Faculty of Medicine, Mustafa Kemal University, Hatay, Turkey

' Faculty of Medicine, Cukurova University, Adana, Turkey

${ }^{d}$ Aksaray State Hospital, Aksaray, Turkey

\section{ARTICLE INFO}

Article history:

Submitted: 27. 7. 2020

Accepted: 6. 9. 2020

Available online: 8. 2. 2021

\section{Klíčová slova:}

Chronická ischemická choroba

srdeční

Perkutánní koronární intervence Prognóza

Troponin T měřený vysoce citlivou metodou

Závažné nežádoucí kardiovaskulární príhody

\section{SOUHRN}

Cíl: Několik studií zkoumalo různé srdeční biomarkery jako prediktory prognózy po perkutánní koronárn intervenci (PCI) u pacientů s chronickou ischemickou chorobou srdeční; výsledky těchto studií jsou však rozporuplné. Stanovování troponinu T vysoce citlivou metodou (high-sensitive troponin T, hs-TnT) představuje novou a přesnější možnost. Cílem této studie bylo zjistit, zda mohou hodnoty hs-TnT sloužit jako prediktor závažných kardiovaskulárních přihod (major adverse cardiovascular events, MACE) v prvním roce po úspěšné plánované $\mathrm{PCl}$ u pacientů se stabilní anginou pectoris (SAP).

Materiál a metody: Do studie bylo zařazeno 100 pacientů s diagnózou SAP a úspěšně provedenou plánovanou PCl. Ze studie byli vyloučeni nemocní se zvýšenými hodnotami troponinu I (>0,1 ng/ml) před výkonem. Hodnoty hs-TnT se stanovovaly před výkonem a v rozmezích 3-4 hodin (časné období) a 12-24 hodin (pozdní období) po výkonu, přičemž za pozitivní byla považována hodnota hs- $\mathrm{TnT}>14 \mathrm{pg} / \mathrm{ml}$. Byla rovněž zaznamenávána incidence MACE v prvním roce.

Výsledky: Hodnoty hs-TnT byly pozitivní u 36 \% pacientů v prvním období a u 54 \% pacientů v pozdním období. Incidence MACE v prvním roce byla významně vyšší u pacientů s pozitivními hodnotami hs-TnT v časném, ne však v pozdním období $(36,1 \%$ vs. $15,6 \% ; p=0,026)$; logistická regresní analýza prokázala poměr šancí ve výši 3,36.

Závěr: Hodnoty hs-TnT naměřené 3-4 hodiny po úspěšné elektivní PCI u pacientů se SAP mohou predikovat incidenci MACE v prvním roce. Tyto výsledky musí nicméně potvrdit větší studie.

(c) 2021, С̆KS

\section{ABSTRACT}

Objective: Several studies have investigated different cardiac biomarkers as predictors of the prognosis after percutaneous coronary interventions $(\mathrm{PCl})$ in patients with chronic ischemic heart disease; nevertheless, the results of these studies are conflicting. High sensitive troponin T (Hs-TnT) measurement is a novel and sensitive method. The aim of this study was to investigate if $\mathrm{Hs}$-TnT levels are a predictor of major adverse cardiovascular events (MACE) in the first year after a successful elective $\mathrm{PCl}$ in patients with stable angina pectoris (SAP).

Material and methods: 100 patients who presented with SAP and underwent successfully elective $\mathrm{PCl}$ were included in the study. Patients with elevated troponin I levels $(>0.1 \mathrm{ng} / \mathrm{mL})$ before the procedure excluded from the study. Hs-TnT levels were measured before the procedure and at 3-4 hours (h) (early period) and 12-24 hours (late period) after the procedure and Hs-TnT level $>14 \mathrm{pg} / \mathrm{mL}$ was considered positive. The incidence of MACE during the first year was recorded.

Results: Hs-TnT levels were positive in $36 \%$ of the patients in the early period and in $54 \%$ of the patients in the late period. The incidence rate of MACE for the first year was significantly higher in the patients with positive Hs-TnT levels in the early period but not the late period $(36.1 \%$ vs. $15.6 \% ; p=0.026)$ and logistic regression analysis yielded an odds ratio of 3.36 .

Conclusion: Hs-TnT levels measured 3-4 h after a successful elective $\mathrm{PCI}$ in patients with SAP can predict the incidence of MACE within the first year. Nonetheless, these results must be corroborated by other larger studies.

\section{intervention}

Prognosis 


\section{Introduction}

Many studies have investigated changes in concentrations of cardiac biomarkers, both before and after $\mathrm{PCl}$, as predictors of short-term and long-term prognosis. These biomarkers are usually troponin $\mathrm{T}$ and $\mathrm{I}$, creatine kinase-muscle/brain (CK-MB), and high sensitive C-reactive protein (Hs-CRP). Cardiac troponin T and I are components of the contractile apparatus of cardiomyocytes and used as biomarkers of myocardial necrosis in patients suspected of having an acute coronary syndrome (ACS). ${ }^{1}$ Moreover, there is a documented relationship between troponin levels and recurrent ischemic coronary events in patients with acute coronary syndromes. ${ }^{2-4}$ It is known that serum troponin levels increase not only during ACS but also the following PCl. ${ }^{5}$ Troponin increases in about one-third of the patients who undergo $\mathrm{PCl}$ and is associated with abnormal microvascular perfusion and necrosis, as determined by cardiac magnetic resonance imaging (MRI). ${ }^{6,7}$ The degree of troponin elevation following $\mathrm{PCl}$ is related to the duration of the procedure, lesion length, development of complications during the procedure, stent implantation, presence of chronic kidney disease, and interventions in more than one artery. ${ }^{8,9}$ Studies on the prognostic value of troponin elevation following $\mathrm{PCl}$ report varying outcomes. Some studies state that even slight elevations in cardiac troponin levels unfavorably influence $\mathrm{PCl}$ outcome while others report that only high levels of cardiac troponin are associated with a poor outcome. ${ }^{10-12}$ Importantly, some studies have failed to determine a relation between troponin positivity after $\mathrm{PCl}$ and poor cardiovascular outcomes. ${ }^{13,14}$ High sensitive troponin $T$ (Hs-TnT) measurement is more sensitive than the conventional method and allows measurement of up to 10-fold lower concentration of troponin T. ${ }^{15}$ High Hs-TnT levels have been associated with long-term adverse events in both NSTE-ACS patients and in stable, high-risk populations. ${ }^{16,17}$ Although Hs-TnT is a sensitive biomarker of cardiac injury that is used in risk stratification, the prognostic significance of post-PCI Hs-TnT levels remains unclear in patients who have undergone elective $\mathrm{PCl}$ for stable angina. Thus, evaluating post- $\mathrm{PCl} \mathrm{Hs}$-TnT levels may be beneficial in identifying patients who may require closer monitoring and more intensive antiaggregant treatment. Therefore, the present study aimed to investigate the prognostic value of pre- and post-procedure Hs-TnT levels on poor cardiovascular outcomes within a one-year follow-up period in the patients undergoing successful elective $\mathrm{PCl}$ for stable angina.

\section{Material and methods}

\section{Patients}

A total of 103 patients had undergone successful elective percutaneous coronary intervention for stable angina was enrolled in the study. The final study population was 100 patients as three patients discontinued the follow-up in the first year. All patients were informed about the study and their informed consent was obtained. The study was approved by the Faculty of Medicine Ethics Committee. Patients presenting with acute coronary syndromes, pre- vious unsuccessful percutaneous coronary intervention, high cardiac troponin levels at presentation, heart failure with reduced ejection fraction, renal insufficiency (estimated glomerular filtration rate; eGFR $<30 \mathrm{~mL} / \mathrm{min} / 1.73$ $\mathrm{m}^{2}$ ), liver insufficiency, metastatic carcinoma, pulmonary embolism, cor pulmonale, moderate/severe pulmonary hypertension, pericardial disease, and patients with less than one-year survival expectancy were excluded from the study.

\section{Sample collection and measurements of high sensitive troponin $T$}

In total three blood samples were drawn for Hs-TnT measurement; i.e., before $\mathrm{PCl}$, between 3-4 hours (h) and between 12-24 $\mathrm{h}$ after $\mathrm{PCl}$. Samples immediately centrifuged at $3000 \mathrm{rpm}$ for $15 \mathrm{~min}$ to separate serum and the serum stored at $-20^{\circ} \mathrm{C}$ till use. After the completion of patient enrollment (approximately six months), all serum samples were analyzed at the laboratory using an "Elecsys ${ }^{\circledR}$ Troponin T high sensitive assay" kit (RocheDiagnostics Limited) according to manufacturer's instructions. The measurement range of the kit is $3-10000 \mathrm{ng} / \mathrm{L}(\mathrm{pg} / \mathrm{mL})$, and Hs-TnT was measured by electrochemiluminescence on a Cobas e 411 analyzers (Roche Diagnostics). An Hs-TnT level >14 $\mathrm{pg} / \mathrm{mL}$ (above the upper limit of the reference range) was scored as positive. CK-MB and CTn-I were measured both before and after $\mathrm{PCl}$ in all patient samples, and $\mathrm{CTn}-\mathrm{I}>0.1$ $\mathrm{ng} / \mathrm{mL}$ (above the upper limit of the reference range) and CK-MB > $4.96 \mathrm{ng} / \mathrm{mL}$ (above the upper limit of the reference range) scored as positive. Patients who presented with stable angina and with no previous coronary angiography (CAG) primarily underwent CAG at the Coronary Angiography Unit. CAG of patients reviewed and those with a lesion causing $70 \%$ or higher stenosis on CAG evaluated for $\mathrm{PCl}$ suitability. $\mathrm{PCl}$ performed by experienced cardiologists on suitable patients. Transthoracic echocardiography was performed and ejection fraction (EF) values were recorded. In addition, the EuroSCORE (European System for Cardiac Operative Risk Evaluation) was calculated for each patient. Prior to $\mathrm{PCl}$, each patient received 300 $\mathrm{mg}$ aspirin and 300-600 mg clopidogrel. Unfractionated heparin was administered at a dose of $100 \mathrm{U} / \mathrm{kg}$ during the procedure and additional doses were administered, as necessary, during the prolonged procedures. After the procedure, the patients have prescribed a maintenance therapy of $100 \mathrm{mg}$ aspirin and $75 \mathrm{mg}$ clopidogrel for one year, in addition to other necessary medications such as statins, ACE inhibitors, and -blockers. The procedure considered successful if TIMI III flow was observed after PCI, the residual lesion was $\leq 20 \%$, and stent thrombosis was absent in the first hour after the procedure. Procedural details such as type (DES or BMS), length, and diameter of the stents implanted, number of diseased vessels, and number of vessels with interventions recorded (interventions grouped as either 1 vessel or $\geq 2$ vessels). In the event of more than one stent is implanted, stent length was considered as the sum of all stents used and stent diameter was that of the narrowest used stent. Stent type was considered as DES even if one of the used stents was DES. Balloon angioplasty was not taken into account for stent-related data (seven patients). The CAG of the patients was reviewed and SYNTAX scores (SYNergy between 
Table 1 - Comparison of demographic variables, clinical data and percutaneous coronary intervention data according to the post-procedural 3-4 $\mathrm{h}$ and $12-24 \mathrm{~h} \mathrm{Hs-TnT}$ value

\begin{tabular}{|c|c|c|c|c|c|c|}
\hline & \multicolumn{2}{|l|}{ 3-4 h Hs-TnT } & \multirow{2}{*}{$p$-value } & \multicolumn{2}{|l|}{ 12-24 h Hs-TnT } & \multirow{2}{*}{$p$-value } \\
\hline & Negative $(n=64)$ & 54) Positive $(n=36)$ & & Negative $(n=46)$ & Positive $(n=54)$ & \\
\hline \multirow{2}{*}{ Age (year) } & $55(37-82)$ & $59(33-90)$ & 0.337 & $55(37-75)$ & $58(33-90)$ & $0.036^{*}$ \\
\hline & $n(\%)$ & $n(\%)$ & & $n(\%)$ & $n(\%)$ & \\
\hline \multicolumn{7}{|l|}{ Gender (n [\%]) } \\
\hline Female & $19(29.7)$ & $7(19.4)$ & \multirow{2}{*}{0.344} & $14(30.4)$ & $12(22.2)$ & \multirow{2}{*}{0.370} \\
\hline Male & $45(70.3)$ & $29(80.6)$ & & $32(69.6)$ & $42(77.8)$ & \\
\hline \multicolumn{7}{|l|}{ Family history (n [\%]) } \\
\hline No & \multirow{2}{*}{$\begin{array}{l}34(53.1) \\
30(46.9)\end{array}$} & $18(50.0)$ & \multirow{2}{*}{0.836} & $24(52.2)$ & $51(51.9)$ & \multirow{2}{*}{1.000} \\
\hline Yes & & $18(50.0)$ & & $22(47.8)$ & $26(48.1)$ & \\
\hline \multicolumn{7}{|l|}{ Hypertension (n [\%]) } \\
\hline No & \multirow{2}{*}{\multicolumn{2}{|c|}{$\begin{array}{l}25(39.1) \\
39(60.9)\end{array}$}} & \multirow{2}{*}{$0.025^{*}$} & $18(39.1)$ & $13(24.1)$ & \multirow{2}{*}{0.131} \\
\hline Yes & & & & $28(60.9)$ & $41(75.9)$ & \\
\hline \multicolumn{7}{|l|}{ Diabetes mellitus (n [\%]) } \\
\hline No & \multirow{2}{*}{\multicolumn{2}{|c|}{$\begin{array}{l}40(62.5) \\
24(37.5)\end{array}$}} & \multirow{2}{*}{0.831} & $28(60.9)$ & $33(61.1)$ & 1000 \\
\hline Yes & & & & $18(39.1)$ & $21(38.9)$ & 1.000 \\
\hline Smoking (n [\%]) & & & & & & \\
\hline No & $33(51.6)$ & $15(41.7)$ & & $23(50.0)$ & $25(46.3)$ & \\
\hline Yes & $19(29.7)$ & $8(22.2)$ & 0.155 & $16(34.8)$ & $11(20.4)$ & 0.073 \\
\hline Quitted & $12(18.8)$ & $13(36.1)$ & & $7(15.2)$ & $18(33.3)$ & \\
\hline Hyperlipidemia (n [\%]) & & & & & & \\
\hline No & $32(50.0)$ & $15(41.7)$ & 0532 & $18(39.1)$ & $29(53.7)$ & 0164 \\
\hline Yes & $32(50.0)$ & $21(58.3)$ & 0.352 & $28(60.9)$ & $25(46.3)$ & 0.104 \\
\hline History of MI (n [\%]) & & & & & & \\
\hline No & $43(67.2)$ & $21(58.3)$ & & $31(67.4)$ & $33(61.1)$ & \\
\hline Yes & $21(32.8)$ & $15(41.7)$ & 0.394 & $15(32.6)$ & $21(38.9)$ & 0.538 \\
\hline Ejection fraction (\%) & 57.5 & 53.1 & 0.160 & 54.8 & 52.4 & 0.606 \\
\hline Body mass index $\left(\mathrm{kg} / \mathrm{m}^{2}\right)$ & 28.2 & 28.1 & 0.600 & 28.4 & 28.1 & 0.874 \\
\hline eGFR $\left(\mathrm{mL} / \mathrm{min} / 1.73 \mathrm{~m}^{2}\right)$ & 111.1 & 108.6 & 0.586 & 116.7 & 100.7 & 0.121 \\
\hline Pre-procedure Hs-TnT (pg/mL) & $3.1(3.0-11.5)$ & $9.8(10.5-19.1)$ & $0.0001 *$ & $3.1(3.0-11.5)$ & $8.0(3.0-19.1)$ & $0.0001^{*}$ \\
\hline EuroSCORE & $1(0-7)$ & $3(0-8)$ & $0.047^{\star}$ & $1(0-7)$ & $2(0-8)$ & 0.099 \\
\hline SYNTAX score & $8(2-35)$ & $10(1-31)$ & 0.191 & $7(2-35)$ & $10(1-31)$ & $0.003^{*}$ \\
\hline Number of diseased vessels & & & & & & \\
\hline 1 vessel & $45(70.3)$ & $20(55.6)$ & 0190 & $34(73.9)$ & $31(57.4)$ & 0096 \\
\hline$\geq 2$ vessels & $19(29.7)$ & $16(44.4)$ & 0.190 & $12(26.1)$ & $23(42.6)$ & 0.050 \\
\hline Number of intervened vessels & & & & & & \\
\hline 1 vessel & $53(83)$ & $27(75)$ & & $39(84.8)$ & $41(75.9)$ & \\
\hline$\geq 2$ vessels & $11(17)$ & $9(25)$ & 0.436 & $7(15.2)$ & $13(24.1)$ & 0.322 \\
\hline & $n=58$ & $n=35$ & & $n=42$ & $n=51$ & \\
\hline Stent length $(\mathrm{mm})$ & $18(9-79)$ & $28(9-92)$ & $0.032^{*}$ & $18(9-79)$ & $28(9-92)$ & $0.004^{*}$ \\
\hline Stent diameter $(\mathrm{mm})$ & $2.7(2.2-4.5)$ & $2.7(2.5-4.5)$ & 0.473 & $2.7(2.2-4.5)$ & $2.7(2.2-4.5)$ & 0.788 \\
\hline Stent type & & & & & & \\
\hline BMS & $24(41.4)$ & $17(48.6)$ & 0.525 & $19(45.2)$ & $22(43.1)$ & 1000 \\
\hline DES & $34(58.6)$ & $18(51.4)$ & $0.5<3$ & $23(54.8)$ & $29(56.9)$ & 1.000 \\
\hline
\end{tabular}

BMS - bare metal stent; DES - drug-eluting stent; eGFR - estimated glomerular filtration rate; Hs-TnT - high sensitive troponin T; $\mathrm{MI}$ - myocardial infarction; * $p$-value $<0.05$ - statistically significant. 
$\mathrm{PCl}$ with TAXUS ${ }^{\mathrm{TM}}$ and Cardiac Surgery) were calculated. Patients were followed up at 1, 6 and 12 months after the procedure to determine the predictive value of $\mathrm{Hs}-\mathrm{TnT}$ for major adverse cardiovascular events (MACE). Cardiac death, acute coronary syndrome [ST-elevation MI (STEMI), NSTEMI, and unstable angina pectoris (USAP)], and stroke defined as MACE. All patients with acute coronary syndrome after the initial PCl underwent CAG (20 patients). The CAGs of the patients reviewed and the type and severity of the lesions (stent thrombosis, stent restenosis and other vascular lesions) recorded. Only patients with critical lesions ( $\geq 70 \%$ ) on CAG were considered as USAP. Stent thrombosis defined as complete occlusion of the stent by thrombotic lesions inside the target vessel and stent restenosis defined as $\geq 70 \%$ stenosis of the stent inside the target vessel. In patients with more than one MACE within the first year, the first event considered as MACE.

\section{Statistical analysis}

The SPSS 17.0 (Chicago, IL) package program was used for statistical analyses of data. Categorical measurements were summarized as number and percentage, whereas continuous variables were represented as a median. The Chi-square test or the Fisher test used for comparing categorical variables (demographic data, gender, cutt-off values of Hs troponin etc.). Distributions compared between groups for continuous variables and the Mann Whitney U-test was used as the data were found to be non-normally distributed (age, stent length, stent diameter, SYNTAX score etc.). Factors influencing the study endpoint (incidence of MACE) were determined using logistic regre- ssion analysis. The level of statistical significance was set at ' $p$ ' $<0.05$ for all tests.

\section{Results}

The study population consisted of a total of 100 patients of whom $26(26 \%)$ were female and $74(74 \%)$ were male. The age of the participants ranged between 33 and 90 years and the mean age was $57.31 \pm 10.3$ years. Hs-TnT was positive in $36(36 \%)$ patients between $3-4 \mathrm{~h}$ and in $54(54 \%)$ patients between $12-24 \mathrm{~h}$ post-PCl. During the course of the one-year follow-up, the incidence of MACE was $23 \%(n=23)$ involving cardiac death $(n=1)$, ACS $(n=20 ; n=5$ STEMI, $n=5$ NSTEMI, $n=10$ USAP), and stroke $(n=2)$. The distribution of lesions causing MACE in patients who developed ACS was as follows: stent thrombosis $(n=4)$, stent restenosis $(n=12)$, new lesions in other than target vessel $(n=4)$. Comparison of demographic variables, clinical data, and percutaneous coronary intervention (PCI) data according to the post-procedural 3-4h and $12-24 \mathrm{~h} \mathrm{Hs}-\mathrm{TnT}$ value, the prevalence of hypertension ( $p$ $=0.025)$, age $(p=0.036)$, pre-procedure Hs-TnT value ( $p$ $=0.0001)$, EuroSCORE $(p=0.047)$, longer stent length ( $p$ $=0.032)$ and SYNTAX score $(p=0.003)$ were significantly higher in the patients with positive Hs-TnT (Table 1). There are no significant differences except male gender in the comparison of demographic variables, clinical data, and percutaneous coronary intervention data according to the presence of one-year MACE have been found (Table 2). Positive Hs-TnT value at 3-4 h post-procedure was statisti-

\begin{tabular}{|c|c|c|c|}
\hline & MACE (-) $n=77$ & MACE $(+) n=23$ & n \\
\hline & Median (min-max) & Median (min-max) & \\
\hline \multirow[t]{2}{*}{ Age (year) } & 56 (33-90) & 56 (37-68) & 0.431 \\
\hline & $n(\%)$ & $n(\%)$ & \\
\hline \multicolumn{4}{|l|}{ Gender } \\
\hline Female & $25(32.5)$ & $1(4.3)$ & \multirow{2}{*}{$0.006^{*}$} \\
\hline Male & $52(67.5)$ & $22(95.7)$ & \\
\hline \multicolumn{4}{|c|}{ Family history } \\
\hline No & $36(46.8)$ & $16(69.6)$ & \multirow{2}{*}{0.062} \\
\hline Yes & $41(53.2)$ & $7(30.4)$ & \\
\hline \multicolumn{4}{|c|}{ Hypertension } \\
\hline No & $25(32.5)$ & $6(26.1)$ & \multirow{2}{*}{0.618} \\
\hline Yes & $52(67.5)$ & $17(73.9)$ & \\
\hline \multicolumn{4}{|c|}{ Diabetes mellitus } \\
\hline No & $46(59.7)$ & $15(65.2)$ & \multirow{2}{*}{0.808} \\
\hline Yes & $31(40.3)$ & $8(34.8)$ & \\
\hline \multicolumn{4}{|l|}{ Smoking } \\
\hline No & $41(53.2)$ & $7(30.4)$ & \multirow{3}{*}{0.142} \\
\hline Yes & $18(23.4)$ & $9(39.1)$ & \\
\hline Quitted & $18(23.4)$ & $7(30.4)$ & \\
\hline \multicolumn{4}{|c|}{ Hyperlipidemia } \\
\hline No & $34(44.2)$ & $13(56.5)$ & \multirow{2}{*}{0.346} \\
\hline Yes & $43(55.8)$ & $10(43.5)$ & \\
\hline
\end{tabular}


Table 2 - Comparison of demographic variables, clinical data and percutaneous coronary intervention data according

to the presence of one-year major adverse cardiovascular events (Continued)

\begin{tabular}{|c|c|c|c|}
\hline & \multirow{2}{*}{$\begin{array}{l}\text { MACE }(-) n=77 \\
\text { Median (min-max) }\end{array}$} & \multirow{2}{*}{$\begin{array}{l}\text { MACE (+) } n=23 \\
\text { Median (min-max) }\end{array}$} & \multirow{2}{*}{$p$-value } \\
\hline & & & \\
\hline \multicolumn{4}{|l|}{ History of MI } \\
\hline No & $49(63.6)$ & $15(65.2)$ & \multirow{2}{*}{0.999} \\
\hline Yes & $28(36.4)$ & $8(34.8)$ & \\
\hline \multicolumn{4}{|l|}{ History of $\mathrm{PCl}$} \\
\hline No & $42(54.5)$ & $14(60.9)$ & \multirow{2}{*}{0.639} \\
\hline Yes & $35(45.5)$ & $9(39.1)$ & \\
\hline \multicolumn{4}{|l|}{ History of CABG } \\
\hline No & $71(92.2)$ & $22(95.7)$ & \multirow{2}{*}{1.000} \\
\hline Yes & $6(7.8)$ & $1(4.3)$ & \\
\hline Systolic blood pressure (mmHg) & $130(85-185)$ & $130(100-170)$ & 0.879 \\
\hline Diastolic blood pressure $(\mathrm{mmHg})$ & $75(45-115)$ & $80(45-95)$ & 0.317 \\
\hline Heart rate (beat/min) & $72(48-110)$ & $70(56-120)$ & 0.667 \\
\hline Body mass index $\left(\mathrm{kg} / \mathrm{m}^{2}\right)$ & $28.1(19.6-48.0)$ & $27.7(21.3-38.8)$ & 0.870 \\
\hline eGFR $\left(\mathrm{mL} / \mathrm{min} / 1.73 \mathrm{~m}^{2}\right)$ & $110.9(37.4-144.0)$ & $111.8(77.7-140.0)$ & 0.353 \\
\hline Ejection fraction (\%) & $60(36-70)$ & $58(25-66)$ & 0.083 \\
\hline Score of EuroSCORE & $1(0-8)$ & $2(0-8)$ & 0.910 \\
\hline Hemoglobin (mg/dL) & $13.5(8.2-17.3)$ & $14.4(11.2-16.8)$ & 0.128 \\
\hline Creatinine (mg/dL) & $0.84(0.4-1.5)$ & $0.8(0.6-1.2)$ & 0.611 \\
\hline Fasting blood glucose (mg/dL) & $102(64-254)$ & $101(82-300)$ & 0.606 \\
\hline LDL (mg/dL) & 105 (33-197) & $94(34-218)$ & 0.550 \\
\hline $\mathrm{HDL}(\mathrm{mg} / \mathrm{dL})$ & $36(23-59)$ & $31(18-51)$ & 0.131 \\
\hline Triglyceride (mg/dL) & $136(32-404)$ & $157(27-648)$ & 0.210 \\
\hline \multirow[t]{2}{*}{ Total cholesterol (mg/dL) } & $168(80-290)$ & $179(78-313)$ & 0.912 \\
\hline & $n=72$ & $n=21$ & \\
\hline Stent diameter (mm) & $2.7(2.2-4.5)$ & $2.7(2.2-4.5)$ & 0.803 \\
\hline Stent length (mm) & $22(9-79)$ & $28(9-92)$ & 0.568 \\
\hline \multirow[t]{2}{*}{ Stent count } & $1(1-3)$ & $1(1-4)$ & 0.766 \\
\hline & $n=77$ & $n=23$ & \\
\hline \multirow[t]{2}{*}{ SYNTAX score } & $8(1-35)$ & $10(2-28)$ & 0.447 \\
\hline & $n(\%)$ & $n(\%)$ & \\
\hline \multicolumn{4}{|l|}{ Number of diseased vessels } \\
\hline 1 vessel & $54(70.1)$ & $11(47.8)$ & \multirow{2}{*}{0.079} \\
\hline$\geq 2$ vessels & $23(29.1)$ & $12(52.2)$ & \\
\hline \multicolumn{4}{|l|}{ Number of intervened vessels } \\
\hline 1 vessel & $64(83.1)$ & $16(69.6)$ & \multirow{2}{*}{0.232} \\
\hline \multirow[t]{2}{*}{$\geq 2$ vessels } & $13(16.9)$ & $7(30.4)$ & \\
\hline & $n=72$ & $n=21$ & \\
\hline \multicolumn{4}{|l|}{ Stent type } \\
\hline BMS & $30(41.7)$ & $11(52.4)$ & \multirow{2}{*}{0.457} \\
\hline DES & $42(58.3)$ & $10(47.6)$ & \\
\hline
\end{tabular}

BMS - bare metal stent; CABG - coronary artery bypass grafting; DES - drug eluting stent; eGFR - estimated glomerular filtration rate; HDL - high-density lipoprotein; Hs-TnT - high sensitive troponin T; LDL - low-density lipoprotein; $\mathrm{MI}$ - myocardial infarction; PCl - percutaneous coronary intervention; * $p$-value $<0.05$ : statistically significant.

cally significant in patients who developed MACE within one year $(p=0.026)$. Among other cardiac biomarkers, post-procedure CK-MB value at $12-24 \mathrm{~h}$ was significantly higher in the MACE group $(p=0.008)$ (Table 3$)$. A regression model was created using variables that were statistically significant during univariate analysis. Logistic re- gression analysis was performed to identify independent risk factors for the development of MACE within one year (odds ratio $=11.31,95 \% \mathrm{Cl} 1.35-94.64 ; p=0.025$ ) and it determined that positive $\mathrm{Hs}-\mathrm{TnT}$ at 3-4 $\mathrm{h}$ post-procedure is a significant risk factor (odds ratio $=3.36,95 \% \mathrm{Cl}$ 1.09-10.33; $p=0.034$ ) (Table 4). 


\begin{tabular}{|c|c|c|c|}
\hline & $\begin{array}{l}\text { MACE }(-)(n=77) \\
n(\%)\end{array}$ & $\begin{array}{l}\text { MACE }(+)(n=23) \\
n(\%)\end{array}$ & $p$-value \\
\hline \multicolumn{4}{|c|}{ Hs-TnT (3-4 h) } \\
\hline Negative & $54(70.1)$ & $10(43.5)$ & \multirow{2}{*}{$0.026^{*}$} \\
\hline Positive & $23(29.9)$ & $13(56.5)$ & \\
\hline \multicolumn{4}{|c|}{ Hs-TnT (12-24 h) } \\
\hline Negative & $38(49.4)$ & $8(34.8)$ & \multirow{2}{*}{0.243} \\
\hline Positive & $39(50.6)$ & $15(65.2)$ & \\
\hline \multicolumn{4}{|l|}{ cTn-I (3-4 h) } \\
\hline Negative & $64(83.1)$ & $16(69.6)$ & \multirow{2}{*}{0.232} \\
\hline Positive & $13(16.9)$ & $7(30.4)$ & \\
\hline \multicolumn{4}{|c|}{ cTn-I (12-24 h) } \\
\hline Negative & $49(63.6)$ & $13(56.5)$ & \multirow{2}{*}{0.626} \\
\hline Positive & $28(36.4)$ & $10(43.5)$ & \\
\hline \multicolumn{4}{|c|}{ CK-MB (3-4 h) } \\
\hline Negative & $66(85.7)$ & $18(78.3)$ & \multirow{2}{*}{0.516} \\
\hline Positive & $11(14.3)$ & $5(21.7)$ & \\
\hline \multicolumn{4}{|c|}{ CK-MB (12-24 h) } \\
\hline Negative & 60 (77.9) & $11(47.8)$ & \multirow{2}{*}{$0.008^{*}$} \\
\hline Positive & $17(22.1)$ & $12(52.2)$ & \\
\hline
\end{tabular}

CK-MB - creatine kinase isoenzyme MB; cTn-I - cardiac troponin I; $\mathrm{Hs}$-TnT - high sensitive troponin T; MACE - major adverse cardiovascular event; " $p$-value <0.05: statistically significant. impaired microvascular perfusion ${ }^{6}$ and necrosis. ${ }^{7}$. Elevated $\mathrm{CTn}$ following $\mathrm{PCl}$ is also associated with duration of the procedure, lesion length, development of complications during the procedure (dissection, lateral branch occlusion, distal embolization, no-reflow phenomenon), stent usage, chronic kidney disease, and interventions in more than one vessel $(8,9)$. Prolonged balloon inflation time, complex vascular structure, and left ventricle dysfunction are other causes of cTn elevation after $\mathrm{PCI}(19,21)$. Post-PCl, the number of hypertensive patients, and the EuroSCORE were significantly higher in patients with positive Hs-TnT only in the early period, while age and SYNTAX score were significantly higher in those with positive Hs-TnT in the late period. Earlier studies have reported the presence of higher $\mathrm{CTn}$ values before $\mathrm{PCl}$ in patients who show post-procedure cTn positivity. Miller et al. reported higher cTn-T values at 8-16 $\mathrm{h}$ post- procedure in those with high initial cTn-T values $(\geq 0.03 \mathrm{ng} / \mathrm{mL})$ compared to those with low initial cTn values $(<0.03 \mathrm{ng} / \mathrm{mL})$ (22).A relationship between post-procedure cTn-I and CTn-T values and long-term mortality has been established(11-13, 18-20). While some studies showed that elevated CTn after $\mathrm{PCl}$ is an independent predictor of mortality $(11,12,18)$, others did not report such an association $(13,19,20)$. It is important to mention here that some of these studies also had patients with $\mathrm{Ml}$ who had higher levels of cardiac biomarkers before $\mathrm{PCI}(12,18,20)$. Kini et al.(13) reported a $16.1 \%$ increase in the rate of CK-MB elevation ( $\geq 16 \mathrm{U} / \mathrm{L}$ ) and $38.9 \% \mathrm{cTn}-\mathrm{I}$ positivity ( $\geq 2 \mathrm{ng} / \mathrm{mL}$ ) after elective $\mathrm{PCl}$ in a study population of 2873 patients (not including high-risk patients). They also suggested that, after an average follow-up period of $12 \pm 6$ months,

\begin{tabular}{|c|c|c|c|c|c|c|c|c|}
\hline & \multirow{2}{*}{ B } & \multirow{2}{*}{ S.E. } & \multirow{2}{*}{ Wald } & \multirow{2}{*}{ Df } & \multirow{2}{*}{$p$} & \multirow{2}{*}{ Odds ratio } & \multicolumn{2}{|c|}{$95 \% \mathrm{Cl}$ for $\operatorname{EXP}(\mathrm{B})$} \\
\hline & & & & & & & Lower & Upper \\
\hline Age & -0.040 & 0.026 & 2.407 & 1 & 0.121 & 0.96 & 0.91 & 1.01 \\
\hline Gender (male) & 2.426 & 1.084 & 5.008 & 1 & $0.025^{*}$ & 11.31 & 1.35 & 94.64 \\
\hline Hs-TnT (3-4 h) & 1.212 & 0.573 & 4.474 & 1 & $0.034^{*}$ & 3.36 & 1.09 & 10.33 \\
\hline CK-MB (12-24 h) & -0.006 & 0.032 & 0.030 & 1 & 0.862 & 0.99 & 0.93 & 1.06 \\
\hline Constant & -1.485 & 1.689 & 0.773 & 1 & 0.379 & 0.23 & & \\
\hline
\end{tabular}

CK-MB - creatine kinase isoenzyme MB; Hs-TnT - high sensitive troponin $\mathrm{T} ; \mathrm{M}$ - male; ${ }^{*} p$-value $<0.05$ : statistically significant.

\section{Discussion}

Minor myocardial injury after successful PCl is quite common and cardiac biomarkers used to assess the extent of injury include CK-MB and cTn. The prevalence of elevated cTn after $\mathrm{PCl}$ has been reported to be between $17 \%$ and $48 \% .{ }^{11-13,18-20}$ However, some of these studies have included $\mathrm{Ml}$ patients with high levels of cardiac biomarkers prior to $\mathrm{PCl} .12,18,20$ The present study comprised patients without ACS and with normal pre-procedure cTn-I levels $(\leq 0.1 \mathrm{ng} / \mathrm{mL})$ in whom Hs-TnT was elevated $(>14 \mathrm{pg} / \mathrm{mL})$ in $36 \%$ of the patients at 3-4 h post-procedure and in $54 \%$ at 12-24 h. Post-procedure elevated cTn is associated with there is a relationship between more than five-fold elevation in CK-MB and cardiac mortality, however post-procedure elevated CTn-I levels do not predict cardiac mortality. Likewise, Natarajan et al.(19), in a study on 1128 low-risk patients observed $17 \%$ cTn-I positivity but without CK-MB elevation after $\mathrm{PCl}$ and observed no relation with adverse cardiovascular outcomes at the end of one-year follow-up. Contrary to these studies, there are studies that suggest a significant relationship between post-procedure cTn levels and adverse cardiovascular outcomes. Prasad et al.(23) have reported cTn-T positivity ( $\geq 0.03 \mathrm{ng} / \mathrm{mL}$ ) without CK-MB elevation after $\mathrm{PCl}$ in $19.6 \%$ of 1949 patients with normal CK-MB and CTn-T values before the procedure and found that post-procedure CTn-T 
positivity was associated with adverse cardiovascular events during a median follow-up period of 26 months. In another report, Prasad et al.(24) divided 5487 patients into groups, who underwent elective $\mathrm{PCl}$, according to pre-procedure and post-procedure CTn-T levels with a 28-month median follow-up period, and suggested that pre-procedure elevated cTn-T levels $(\geq 0.01 \mathrm{ng} / \mathrm{mL})$ are a predictor of mortality within one month and that post-procedure elevated cTn-T levels $(\geq 0.01 \mathrm{ng} / \mathrm{mL})$ are associated with 30-day mortality. The present study consisted of patients who presented with stable angina, had normal cTn-I levels (cTn-I $\leq 0.1 \mathrm{ng} / \mathrm{mL}$ ) before the procedure and underwent successful, elective PCI. MACE development was analyzed at one year and significant relationship was determined between post-procedure early Hs-TnT positivity $(36.1 \%$ vs. $15.6 \% ; p=0.026)$. Further, even though the incidence of MACE at one year was higher in patients with post-procedure late Hs-TnT positivity, this was not statistically significant $(27.8 \%$ vs. $17.4 \% ; p=0.243)$. A regression model used to identify factors that independently affected MACE occurrence and it was found that post-procedure early Hs-TnT positivity was a significantly associated with MACE (odds ratio=3.36, 95\% Cl 1.0910.33; $p=0.034)$. Further analyses of MACE development during the first year using a cTn-I cut-off value of greater than $0.1 \mathrm{ng} / \mathrm{mL}$ revealed no significant differences between these two groups. This may be attributed to the fact that Hs-TnT is more sensitive than cTn-I. These results imply that Hs-TnT is a better biomarker than CTn-I in predicting risk of MACE development after $\mathrm{PCl}$ and also provides better prognostic information. A similar analysis for CK-MB revealed post-procedure late CK-MB positivity was significantly higher in the group that developed MACE at one year $(p=0.008)$. Such a significant elevation in post-procedure late period is probably due to the fact that CK-MB is detectable only in the later periods following myocardial injury. Nonetheless, this significance disappeared during logistic regression analysis. Two potential explanations exist for the observed elevations in cardiac biomarkers after $\mathrm{PCl}$ and the incidence of MACE. The first uses a positive correlation between the magnitude of myocardial, injury, and CTn secretion and the fact that cTn is known to be elevated after $\mathrm{PCl}$ and myocardial injury, as documented by MRI. Consequently, myocardial injury may impair left ventricle function and lead to life-threatening arrhythmia. The alternative explanation is that elevated CK-MB and CTn values may also be markers of severe atherosclerosis, increased plaque burden, presence of sensitive plaque, endothelial dysfunction, microvascular injury, and inflammation, and that inflammation is an independent predictor of long-term adverse events after $\mathrm{PCl}^{23}$ Given this, we can conclude that both post-procedure early (3-4 h) Hs-TnT positivity and late (12-24 h) CK-MB positivity are associated with one-year MACE development in patients with stable angina undergoing successful, elective $\mathrm{PCl}$. Importantly, separating the effects of post-PCI Hs-TnT positivity on MACE development in early and late periods is unique to this report and, to the best of our knowledge, is the first of its kind. In our study, the only clinical risk factor affecting MACE development in 1 year was male gender. In a meta-analysis involving 13 randomized controlled trials published by
Chen et al. ${ }^{5}$ ). It has been reported that MACE rates are more common in female gender in the short-term and long-term after coronary stenting. The reason for this inconsistent finding in our study may be the low number of female patients in the study population ( $74 \%$ male, $26 \%$ female). There are some limitations of our study must be emphasized. The number of patients in the present study is only 100 and the prognostic usefulness will be better understood with larger studies. Also the follow-up period was limited to one year and it is possible that Hs-TnT after $\mathrm{PCl}$ is relevant for long-term prognosis as well. Prognostic assessment for mortality could not be performed as death was an infrequent outcome during follow-up. The distribution of risk factors among the groups with and without Hs-TnT positivity after PCl was not homogenous and only the global effects of these factors on MACE development, rather than their individual effects, may be evident. Some of the patients did not complete all follow-up visits, had to be reached by phone, and evaluated at the closest health center. Thus, it is possible that information so obtained may not be completely accurate. Secondary endpoints such as incidence and degree of angina pectoris, hospitalization for heart failure, and asymptomatic stent restenosis were not included and therefore, follow-up visits did not specifically address these issues.

\section{Conclusion}

In conclusion, post-procedure early period Hs-TnT measurement may provide prognostic benefit (prognostic marker of MACE incidence) in the patients who undergo $\mathrm{PCl}$ for stable angina, but larger studies are required to adequately verify this information.

\section{Conflict of interest}

All authors declare that they do not have conflict of interest.

Funding

None.

\section{Ethical statement}

Cukurova University, Faculty of Medicine, ethics committee - (09.02.2012/5).

\section{References}

1. Gupta S, de Lemos JA. Use and misuse of cardiac troponins in clinical practice. Prog Cardiovasc Dis 2007;50:151-165.

2. Peacock WF, Baumann BM, Bruton D, et al. Efficacy of HighSensitivity Troponin T in Identifying Very-Low-Risk Patients With Possible Acute Coronary Syndrome. JAMA Cardiol 2018:3:104-111.

3. Lindahl B, Toss $\mathrm{H}$, Siegbahn A, et al. Markers of myocardial damage and inflammation in relation to long-term mortality in unstable coronary artery disease. N Engl J Med 2000;343:1139-1147.

4. Eggers KM, Jernberg $\mathrm{T}$, Lindahl B. High-sensitivity cardiac troponin T, left ventricular function, and outcome in non-ST elevation acute coronary syndrome. Am Heart J 2018;197:7076.

5. Zhao XY, Wang XF, Zhang JY, et al. Effect of the composition of atherosclerotic plaques and rate of platelet aggregation 
on elevation of serum levels of cardiac troponin T after percutaneous coronary interventions. J Interv Cardiol 2012;25:433-438.

6. Bolognese L, Ducci K, Angioli P, et al. Elevations in troponin I after percutaneous coronary interventions are associated with abnormal tissue-level perfusion in high-risk patients with nonST-segment-elevation acute coronary syndromes. Circulation 2004;110:1592-1597.

7. Selvanayagam JB, Porto I, Channon K, et al. Troponin elevation after percutaneous coronary intervention directly represents the extent of irreversible myocardial injury: Insights from cardiovascular magnetic resonance imaging. Circulation 2005; 111:1027-1032

8. Cavallini C, Verdecchia P, Savonitto S, et al. Prognostic value of isolated troponin I elevation after percutaneous coronary intervention. Circ Cardiovasc Interv 2010;3:431-435.

9. Saleh N, Svane B, Velander M, et al. C-reactive protein and myocardial infarction during percutaneous coronary intervention. J Intern Med 2004;255:33-39.

10. Nageh T, Sherwood RA, Harris BM, et al. Cardiac troponin T and $I$ and creatine kinase-MB as markers of myocardial injury and predictors of outcome following percutaneous coronary intervention. Int J Cardiol 2003;92:285-293.

11. Nallamothu BK, Chetcuti S, Mukherjee D, et al. Prognostic implication of troponin I elevation after percutaneous coronary intervention. Am J Cardiol 2003;91:1272-1274.

12. Kizer JR, Muttrej MR, Matthai WH, et al. Role of cardiac troponin $\mathrm{T}$ in the long-term risk stratification of patients undergoing percutaneous coronary intervention. Eur Heart J 2003;24:1314-1322.

13. Kini AS, Lee $P$, Marmur JD, et al. Correlation of postpercuteneous coronary intervention creatine kinase-MB and troponin I elevation in predicting midterm mortality. Am J Cardiol 2004;93:18-23.

14. Brauer M, Bode E, Metzler B, et al. Post-interventional cardiac biomarker release has lower prognostic relevance compared with standard risk markers in patients with stable coronary artery disease undergoing elective percutaneous coronary interventions. Int J Cardiol 2013;168:4864-4865.
15. Omland T, Lemos JA, Sabatine MS, et al. A sensitive cardiac troponin T assay in stable coronary artery disease. N Engl J Med 2009;361:2538-2547.

16. Ndrepepa G, Braun S, Schulz S, et al. Comparison of prognostic value of high-sensitivity and conventional troponin $\mathrm{T}$ in patients with non-ST-segment elevation acute coronary syndromes. Clin Chim Acta 2011;412:1350-1356.

17. Kavsak PA, Xu L, Yusuf S, McQueen MJ. High-sensitivity cardiac troponin I measurement for risk stratification in a stable highrisk population. Clin Chem 2011;57:1146-1153.

18. Cantor WJ, Newby LK, Christenson RH, et al. Prognostic significance of elevated troponin I after percutaneous coronary intervention. J Am Coll Cardiol 2002;39:1738-1744.

19. Natarajan MK, Kreatsoulas C, Velianou JL, et al. Incidence, predictors, and clinical significance of troponin-I elevation without creatine kinase elevation following percutaneous coronary interventions. Am J Cardiol 2004;93:750-753.

20. Cavallinin C, Savonitto S, Violini R, et al. Impact of the elevation of biochemical markers of myocardial damage on long-term mortality after percutaneous coronary intervention: results of the CK-MB and PCl study. Eur Heart J 2005;26:1494-1498.

21. Nageh T, Sherwood RA, Harris BM, Thomas MR. Prognostic role of cardiac troponin I after percutaneous coronary intervention in stable coronary disease. Heart 2005;91:1181-1185.

22. Miller WL, Garratt KN, Burritt MF, et al. Baseline troponin level: key to understanding the importance of post- $\mathrm{PCl}$ troponin elevations. Eur Heart J 2006;27:1061-1069.

23. Prasad A, Singh $M$, Lerman A, et al. Isolated elevation in Troponin $\mathrm{T}$ after percutaneous coronary intervention is associated with higher long-term mortality. J Am Coll Cardiol 2006;48: 1765-1770.

24. Prasad A, Rihal CS, Lennon RJ, et al. Significance of periprocedural myonecrosis on outcomes after percutaneous coronary intervention: An analysis of preintervention and postintervention troponin T levels in 5487 patients. Circ Cardiovasc Interv 2008;1:10-19.

25. Chen Z, Qian J, Ma J, et al. Effect of gender on repeated coronary artery revascularization after intra-coronary stenting: a meta-analysis. Int J Cardiol 2012;15:381-385. 